Abstract

Three buildings are cited in this paper, which have become the materialized expressions of certain architectural theories; the Scröder House by Gerrit Rietveld, The Jubilee Church by Richard Meier and the Superlofts project by Marc Koehler

Architects. The chosen exemplars belong to different instances in recent history -the former to the early twentieth, the second to the late twentieth and the last one to the twenty-first centuries- and they seem to reflect the state of mind and intention of their architects as well as the general spirit of the architectural milieus of their times. Understanding the buildings themselves and the theories behind them would provide an insight about how the theoretical discourse in the field of architecture has evolved in decades and how architects have responded to this evolution in regard to their contributions to architectural theory.

$\ddot{O} z$

Mimari yapılar, çoğu durumda, kendilerini tasarlayan mimarın kuramsal duruşuyla birlikte yapıldıkları dönemlerin genel mimarlı ruhunu yansitan örneklerdir. Bu makalede, belirli mimarlık kuramlarının somutlaştırılmış ifadesi haline gelmiş üç yapr ele alınmaktadir; Gerrit Rietveld'in tasarladı ̆̆ Schröder Evi (1924), Richard Meier tasarımı Jübile Kilisesi (1996-2003) ve Marc Koehler Mimarlık'ın geliştirdiği Superlofts Projesi (2015). Sözkonusu yapılar ilki erken yirminci yüzyll, ikincisi geç yirminci yüzyll ve sonuncusu da yirmibirinci yüzyıldan olmak üzere, yakın tarih içerisindeki üç farklı anı temsil etmek üzere, söylemsel olarak sirastyla Modernizm, Postmodernizm ve Sürdürülebilir Mimarlı̆̆ın kuramsal alanda etkin olduğu dönemlerden seçilmiştir: Bu yapıları ve arka planlarında barındırdıkları teorik yaklaşımları anlamak, mimarlık kuramının yakın onyıllar içerisindeki dönüşümüne ve mimarların bu dönüşüme nasıl uyum sağladıklarına ışık tutacaktır.

Keywords: Arhitectural theory, TheoryPratice Relation in Architecture, Modernism, Postmodernism, Sustainable Architecture

Anahtar Kelimeler: Mimarlık Kuram Mimarlıkta kuram-uygulama iliskisi. Modernizm, Postmodernizm, Sürdürülebilir Mimarlık
Bu makale, 28 Eylül $2018^{\prime}$ de ARCHTHEO'I8
sempozyumu'nda çağrılı konuşma olarak sunulan bildiri metninden uyarlanmıştır.

\title{
Architecture as the Built Form of Theory"
}

(D) Ebru Özeke Tökmeci Mimar Sinan Güzel Sanatlar Üniversitesi Mimarlık Fakültesi, Mimarlık Bölümü, Kabul tarihi/Final Acceptance: 01.03.2019

\section{Introduction}

It would be fundamental to first try to understand the scope of the term architectural theory. In fact, it is not likely to make an all-inclusive designation for this, since the contents of the field have changed through cultures, societies and different time periods in history.

Harry Francis Mallgrave defines architectural theory as simply the history of our ideas regarding our constructed physical surroundings $(2007, X X I)$.

Kate Nesbitt states that, within the discipline of architecture, theory is a discourse that describes the practice and production of architecture and identifies challenges to it $(1996,16)$. According to Hanno-Walter Kruft, architectural theory comprises any written system of architecture that is based on aesthetic or functional categories (1994, 15). Mallgrave also states that, theory possesses no tangible form; it exists in large and heavy tomes as well as in short and spirited manifestoes $(2007, X X I)$. Thus, a set of architectural theory might come in the form of a handbook or a guide of practical building instructions as well as a reflection on the aesthetical, social or practical approaches to architecture within a certain era. It might comment on one single building or be a compilation of commentaries on buildings with similar or different characteristics. It might portray an approach to the art of building and this approach, emerging at a definite period of time, might belong to a certain society as well as to a certain individual.

Much a collection of these thoughts, Virgilio Onofrei states that the theory of architecture considers the whole sphere of architecture as a study matter and has applications in fields belonging both to the practice and to the knowledge, such as architectural experience, architectural design, research, history and also criticism. Each of these application fields goes through its own dynamic process, and, in its turn, the theory of architecture, having multiple interconnections with them, is a complex subject, in a continuous evolution (2005, 125).

I should note here that a particular attempt has also been made to define the desired relationship between architectural theory and architectural practice, the main question being 'how is the world of buildings combined with the world of ideas?' This seems quite challenging because on the one hand theory can be seen as a set of reflections complementing, justifying and intellectualizing what has already been built, while on the other hand, it lays down programs and requirements for architecture to fulfill; it deals with architecture's 
aspirations as much as its accomplishments (Nesbitt 1996, 16). In other words, architectural theory investigates how and why things happen to be the way they are while also trying to define how they should be.

Nesbitt $(1996,19)$ also points out to the debate on whether theory must be applicable useful knowledge and whether it must result in predictable outcomes in design. $\operatorname{Kruft}(1994,17)$ concludes that it is only in dialogue with each other that architectural theory and architecture itself can flourish. Theory can be a statement, a codification of practice or a program and the quality of the corresponding architecture serves as a gauge of the usefulness of the theory. This leads him to the idea that it must be possible to check architectural theory by reference to actual buildings.

In light of such conclusion, three buildings will be cited in this paper, which have become the materialized expressions of certain architectural theories; the Scröder House by Gerrit Rietveld, The Jubilee Church by Richard Meier and the Superlofts project by Marc Koehler Architects. The chosen exemplars belong to different instances in recent history -the former to the early twentieth, the second to the late twentieth and the last one to the twenty-first centuries- and they seem to reflect the state of mind and intention of their architects as well as the general spirit of the architectural milieus of their times. Understanding the buildings themselves and the theories behind them would provide an insight about how the theoretical discourse in the field of architecture has evolved in decades and how architects have responded to this evolution in regard to their contributions to architectural theory.

\section{The Schröder House}

The first building; the Schröder House was built in Utrecht, by Gerrit Rietveld in 1924 (Figure 1). Rietveld (1888-1964) was actually a craftsman, a furniture designer and architect and he was also one of the principal members of the Dutch artistic movement De Stijl. The artistic principles that were brought about in the Netherlands through the First

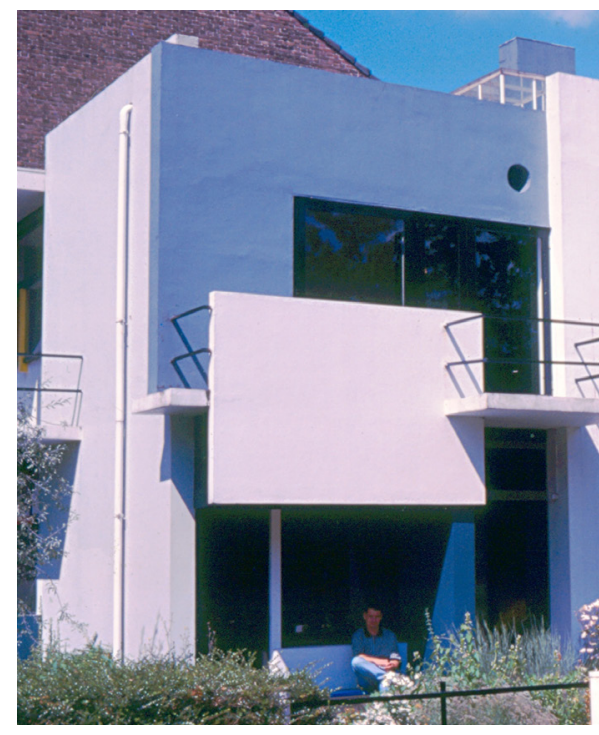

World War years were manifested in the periodical publication De Stijl, published between 1917-31 by its founder and co-editor Theo van Doesburg (1883-1931). The magazine was a forum for discussing new directions in modern art and as is widely recognized, its contributors were in search of a kind of abstract art which was not representational, illustrative or narrative as art was before. On the contrary, this new way of art had to bear no relation to the world of objects or to the imitation of shapes (Warncke 1991, 10).

Among the many names that were associated with the De Stijl Movement, the Dutch painter Piet Mondrian (1872-1944) stood out for his contribution to the forum with the introduction of Neoplasticism, while Rietveld's Red-Blue Chair and Schröder House were to be listed among the classics of avant-garde design and van Doesburg (1922, 92-94) defined the new style that the new era was calling for. It was the style of the perfect man, a style of liberation and vital repose, the style in which the great opportunities were reconciled. According to him, the characteristics of the new style in opposition to the old were; certainty instead of uncertainty, openness instead of enclosure, clarity instead of vagueness, religious energy instead of faith and religious authority, truth instead of beauty, simplicity instead of complexity, relationship instead of form, synthesis instead of 
Figure: 2

Doesburg defended the plastic richness of an all-sided development in space and time: there is no repetition, no street front of a building and no standardization.

Figure: 3

According to Doesburg, the window plays an active role in opposition to the closedness of the wall surface. analysis, logical construction instead of lyrical constellation, mechanization instead of manual work, plastic form instead of imitation and decorative ornamentation, collectivism instead of individualism.

Architecture was a particular focus of attention for the De Stijl group.

According to Doesburg, the challenge was to transfer the principles of fine art to architecture (Kruft 1994, 379) and in the $7^{\text {th }}$ volume of the De Stijl magazine he published his article Towards a Plastic Architecture where he put out the 16 points which were to define the orientation of the new architecture.

Here, Doesburg (1924, 64-66) considered the elimination of all concepts of form in the sense of a fixed type as an essential to the healthy development of architecture and art as a whole. He wrote, instead of using earlier styles as models and imitating them, the problem of architecture must be posed entirely afresh. He would state that the new architecture should be elemental, economic and functional while it should also be open. That is to say that the whole structure consists of a space that is divided in accordance with the various functional demands. This division is carried out by means of dividing surfaces which separate the various functional spaces and which should be movable. The dividing surfaces may be replaced by movable intermediate surfaces or panels.

According to Doesburg, the new architecture had opened the walls and so done away with the separation of inside and outside. The walls themselves no longer support; they merely provide supporting points. The result is a new, open groundplan entirely different from the classical one, since inside and outside now pass over into one another.

Doesburg stood against frontalism which had its origin in a rigid, static way of life, and defended the plastic richness of an all-sided development in space and time. He would state that the new architecture had eliminated both monotonous repetition and the stiff quality of two halves - the mirror image, symmetry. There is no repetition in time, no street front, no standardization (Figure 2).

Deosburg would also state that, the new architecture possessed no single passive factor. It had overcome the opening (in the wall). With its openness, the window plays an active role in opposition to the closedness of the wall surface. Nowhere does an opening or a gap occupy the foreground; everything is strictly determined by contrast (Figure 3).
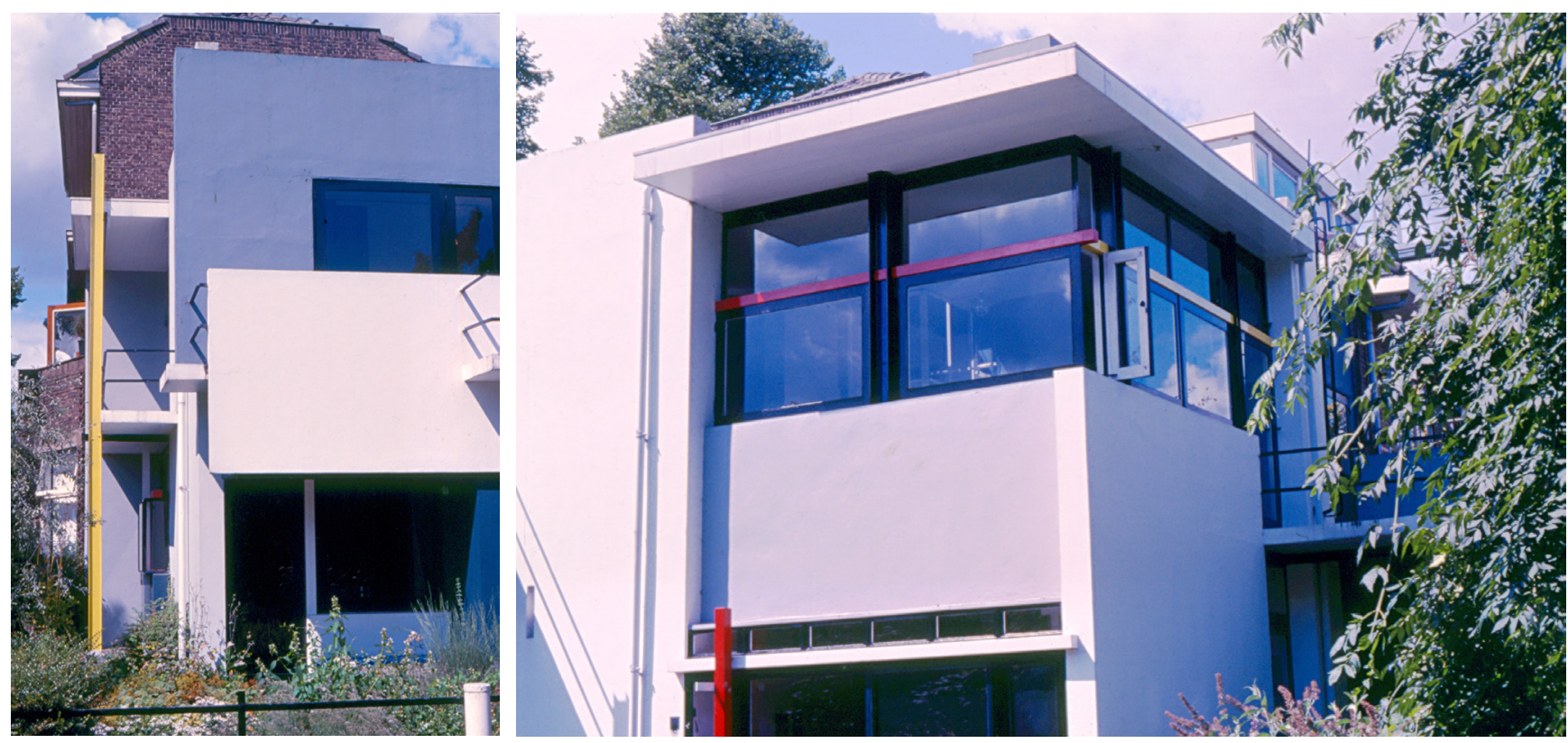
Kruft defines the Schröder House as the most striking practical expression of these ideas (1994, 380). According to Frampton $(1997,145)$, the house was in many respects a realization of Theo van Doesburg's manifestation of 16 Points of a Plastic Architecture as it was elementary, economic and functional; un-monumental and dynamic; anti-cubic in its form and anti-decorative in its color as already prescribed. Its main living level on the top floor, with its open transformable plan exemplified the theory of a dynamic architecture liberated from the burden of load-bearing walls and the restrictions imposed by pierced openings. The house was also anti-cubic in the sense that it did not try to freeze the different functional space cells in one closed cube but rather threw the functional space cells centrifugally from the core of the cube.

Architects of the early modern era were much influenced by the new forms of abstract painting and sculpture then being produced by the avant-garde and De Stijl architects were particularly interested in the work of Mondrian. Taking his linear compositions as models, the building forms were treated as abstract compositions of lines and planes to define a new concept of architecture as a pure art form (Abel 1988, 172). In this sense, the Schröder house can also be considered as a Mondrian painting raised in three dimensions, conforming to an artistic method of theory which regards the building forms themselves as visual compositions (Figure 4).

\section{The Jubilee Church}

The Church of 2000 or the Jubilee Church by Richard Meier (b. 1934) was designed in 1996 for an international competition established by the Vatican's initiation of the 50 Churches for Rome 2000 project. Six contemporary architects were invited to the competition to submit their proposals. The intention was to show and highlight the basic role that architecture would play in holy and religious spaces and also to demonstrate that the connection with contemporary architecture is the key to improve the quality of life in suburban areas. The construction of Meier's winning

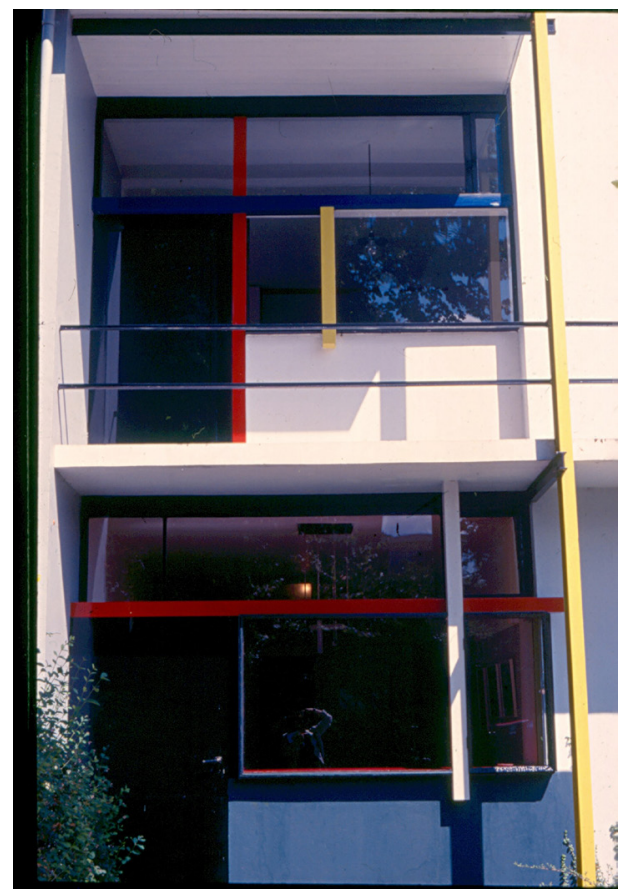

Figure: 4

A Mondrian painting raised in three dimensions project for this church, however, could not be completed until 2003, due to financial problems (Figure 5).

Richard Meier is one of the prominent figures of contemporary architecture whose career dates back to the 1960's. His early works were among the work of five New York Architects along with Michael Graves (1934-2015), John Hejduk (19292000), Charles Gwathmey (1938-2009) and Peter Eisenman (B.1932), also referred to as the Whites. Brought together in a 1972 book, namely Five Architects, the works of these architects reemployed the rational forms of the Modern Movement with an obviously Corbusian orientation (Rowe 1975, 7). According to Frampton (1997, 311), this was an attempt made in the second half of the 1960's, to develop a theoretical and artistic production as rigorous as that achieved by the pre-war European avant-garde. Since then and all through his career, Meier has kept to a form of aestheticised functionalism which he sees as belonging to a great historical tradition while he rejects the use of ornament (Kruft 1994, 444). As such, he has secured himself a reputation as one of the most civic-minded architects of his generation (Frampton 1997, 311).

4 Sayı 27, Mayıs 2019 
Figure: 5

The Jubilee Church, Richard Meier, Rome 1996-2003.
Figure: 6

Whiteness reflects nature, it refracts light, it makes one more aware of the colors of nature.

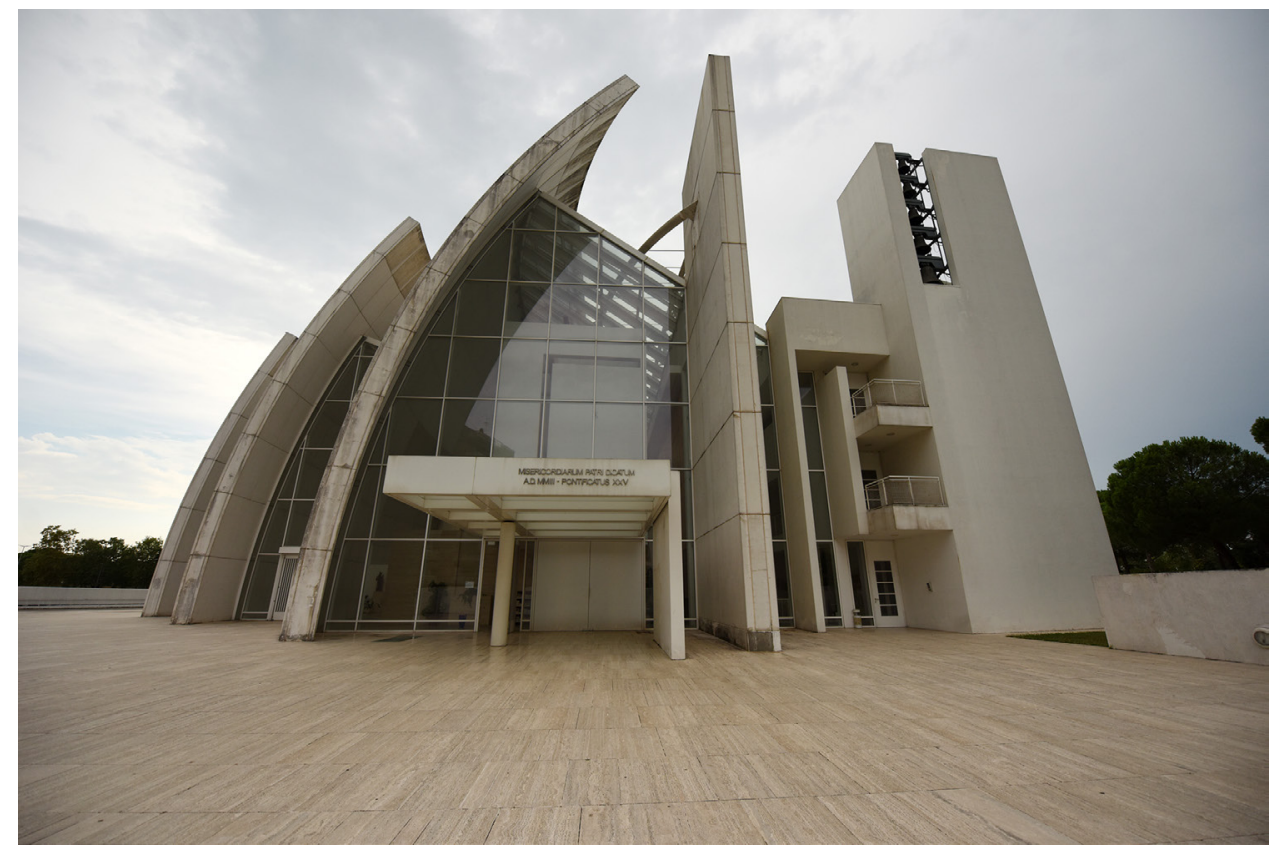

The principles that guide Meier's work are rooted in timeless, classical design issues such as Site, Order, and the use of Natural Light that are not unique to period, style, or context (url 1). His work is characterized by the rational use of geometry, the clarity of their spaces, the superb handling of light and the use of white as a symbol of purity. The Jubilee Church consists of two elements; the church itself and the parish center with offices, an auditorium and a multipurpose hall. The two buildings are separated by a wall plane and they are joined by the concave wall of glass on the facade of the building. Thus, the overall structure is conceived as a composition of basic geometrical forms -the sphere and the cube referring to their purity- and the contrast between them. The main space of the church is the connection point of these two forms.

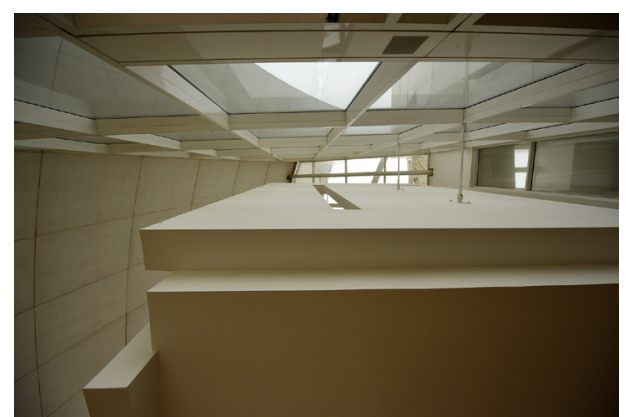

According to Meier, architecture is expressing a quality of light. It should also allow one to appreciate nature that's around. White is all colors. It's everywhere. Everywhere one looks. Whiteness, in a sense, reflects nature, it refracts light, it makes one more aware of the colors of nature because of the whiteness of the buildings (Bianchini 2018) (Figure 6).

Meier would state that the central ideas for creating a sacred space have to do with truth and authenticity, a search for clarity, peace, transparency, a yearning for tranquility, a place to evoke otherworldliness in a way that is uplifting. And to express spirituality, the architect has to think of the original material of architecture which is space and light (Riding 2003). Accordingly, the Jubilee Church building uses as much natural light as it comes in through the glazed glass roof between the shells (Figures 7, 8).

While the major expressive issue and the essence of architecture through the Modern Movement was its function which was seen as rational and scientific, Postmodernism placed a higher value on form than on function asserting that the form itself is the essence or content of architecture (Nesbitt 1996, 45). This postmodern attitude was also much concerned with issues of 


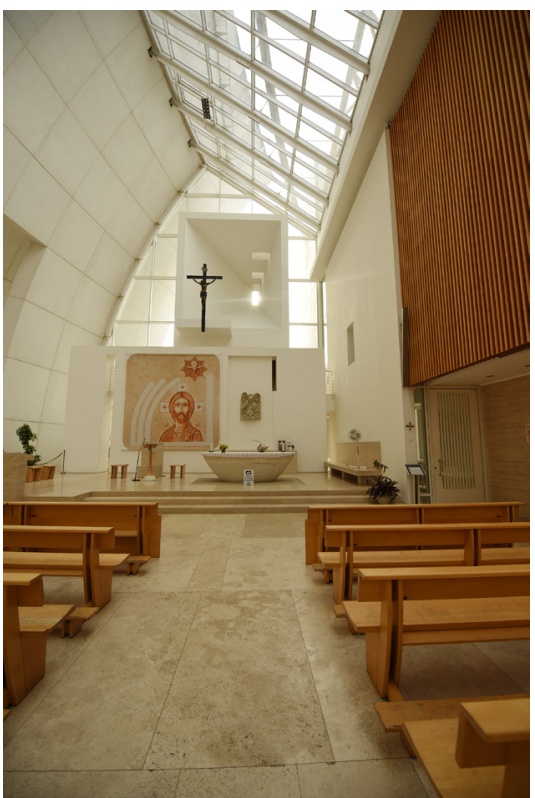

meaning in architecture bringing forth the argument that 'every building component, from structural to ornamental, accommodates a meaning due to particular local and cultural codes.' Such discussion has often tried to formulate a possible correspondence between architecture and language to transfer the concept of metaphor into the field of architecture.

As a building conforming to postmodern architectural language, the Jubilee Church also accommodates in itself a symbolic meaning through the metaphors that it employs. The three enormous circular shells represent the Holy Trinity. They give a feeling of lightness to the building while they also symbolize the movement of the mounting waves or sails as the building takes on the idea of a ship sailing into the seas of the third millennium (Dannels).

\section{The Superlofts}

In the twenty first century one can see that the scope of architectural theory has become even wider with the introduction of new concepts into the discourse. In the pluralistic culture of today's world, one can find a large number of theoretical models to choose from. Among the many, a tendency towards ecological resilience seems to have dominated the field of architecture since the late $20^{\text {th }}$ century.

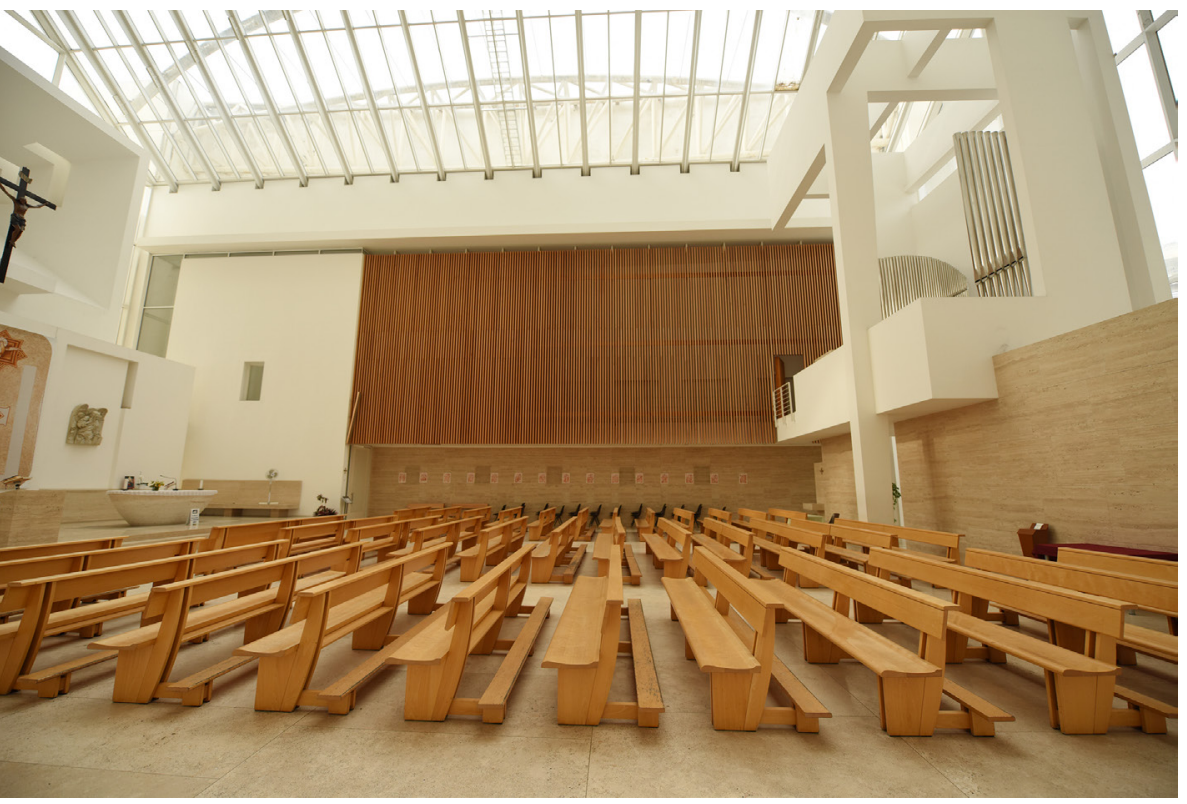

While the idea that a building should be produced in accordance with first the nature and later the built environment seems as old as the appearance in history of the human-made settlements, the consciousness regarding environmental problems and artistic practice gained acceleration after the second half of the 1960s. Through the following decades, respect for the environment encouraged the use of technologies that are compatible with it and the end of the $20^{\text {th }}$ century witnessed the emergence of Sustainable Architecture. The term sustainable comes from the concept of sustainable development, which is understood as satisfying the present necessities without creating future developmental problems and without compromising the demands of future generations (Chust 2014, 230). The influence of sustainability in architecture has inspired many architects as well as producing a vast amount of scholarly theory.

Superlofts in this sense, is a new co-housing concept developed by Marc Koehler $(b$. 1977) Architects [MKA], an international design agency founded in 2005 by Marc Koehler who represents a younger generation of architects. In search of a socially responsible way of making buildings, MKA has taken sustainability in architecture as a key concept in all its production trying to create valuable connections between build-
Figure: 7

The central ideas for creating a sacred space have to do with truth and authenticity. Figure: 8

The Jubilee Church building uses as much natural light as it comes in through the glazed glass roof between the shells. 
Figure: 9

The Superlofts Block Y, Marc Koehler Architects, Utrecht, 2014-2017 (url 2).

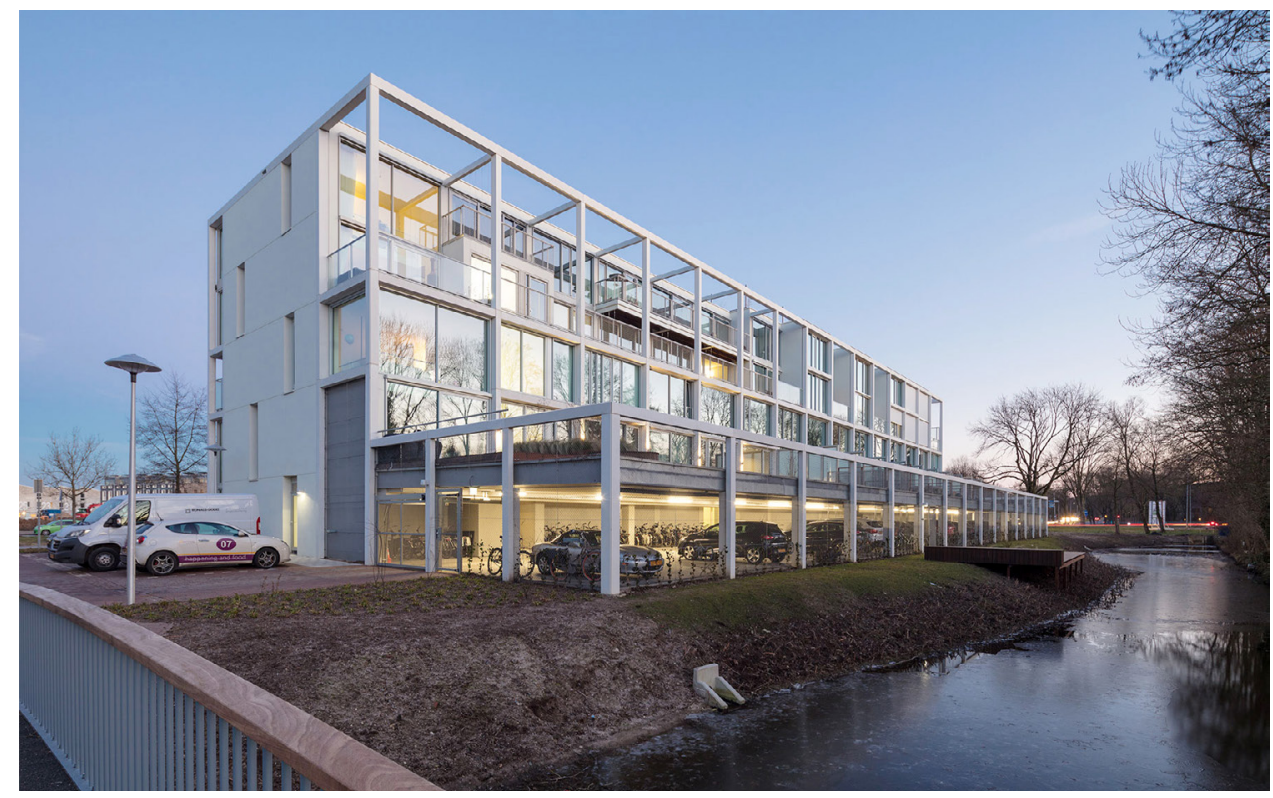

Figure: 10

The Superlofts Houthavens, Amsterdam, 2016 (url 3).

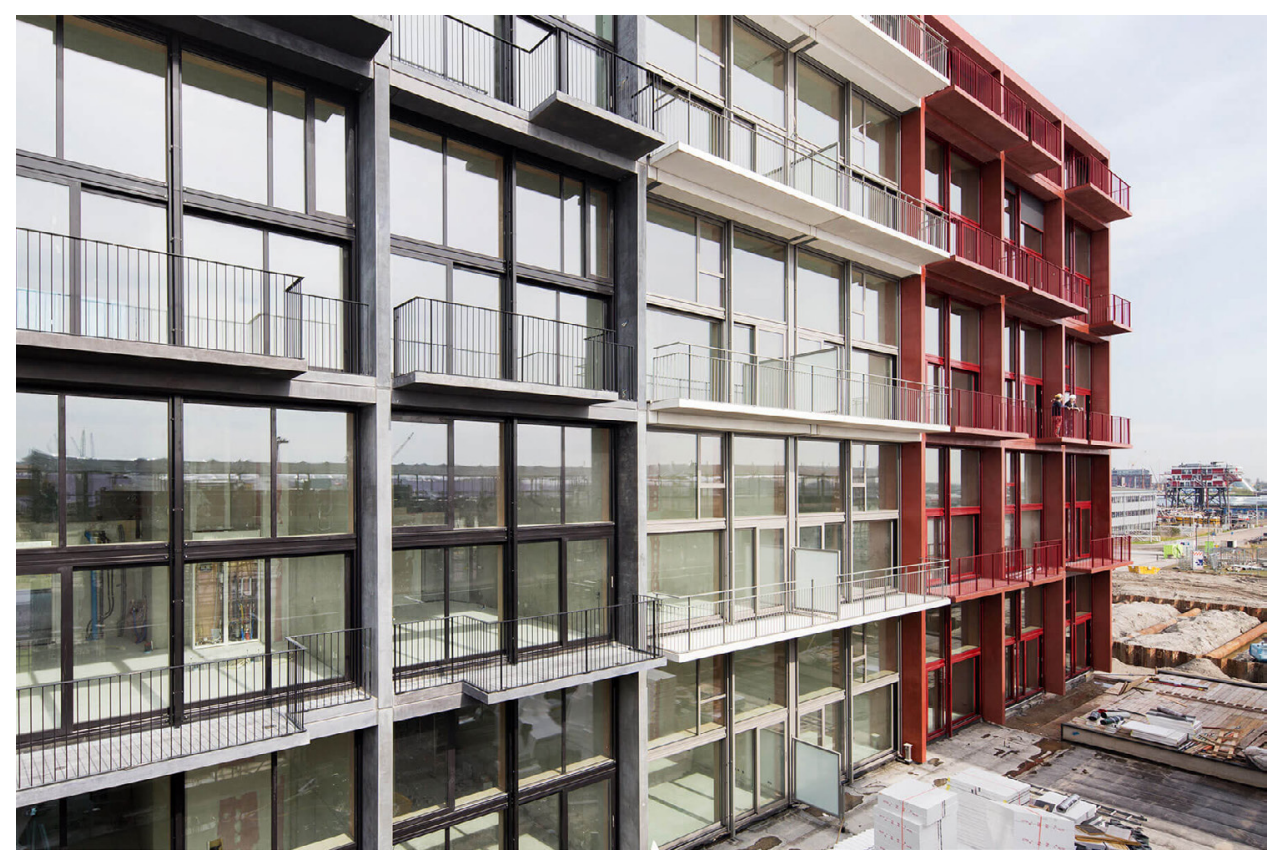

ings and their environment, the culture of its users and the latest technical possibilities (Figure 9).

Superlofts (url 4) is a customisable co-living and development model based on modular and Open Building systems. Superlofts offers its members the freedom to customise or design their homes from scratch incorporating any hybrid function, and co-create shared spaces to build a global co-living community. Superlofts are designed as Open Buildings that separate the permanent support structure from the temporary infills, utilising a flexible and open framework that easily adapts to changing cycles of use and maintenance. This facilitates a circular way of building and, importantly, contributes to resilient cities that can accommodate the changing urban programmes and lifestyles of the people who inhabit them. Each project integrates the latest sustainable technologies that support efficient and healthy buildings in the long term (Figure 10). 
Koehler (Winston 2017) states that consumers are becoming co-creators of the stuff they buy and believes that the same can be applied to the housing sector where there is a huge demand for more quality. More quality, for him, means more personalization of the domestic sphere and for that one needs to create buildings that can adapt to those personal requirements.

The system is proven to be highly adaptable to different sites and has already been applied in the Netherlands and abroad.

\section{Conclusion}

The evolution of architectural forms is the result of the change in the ideals that produced them as well as the motives which dictate the character of the work of the architect. Architecture as an end product concerns mainly what a building looks like, how it is constructed and how efficiently it fulfills its purpose. However, the architects who create the buildings are obliged to be equally concerned with more speculative questions (Collins 1998, 16).

While considering different factors through the design process such as location, social form, technology and so on, the values the architect attaches to these factors and to the relation between them are determined according to a theoretical model of architecture (Abel 1988, 163). Thus, an architect arrives at the finished product by first thinking of forms intuitively, then trying to justify them rationally by what we may call one's individual theory of architecture (Collins 1998, 16).

Nesbitt states that $(1996,17)$, architectural theory can be characterized by several attitudes towards the presentation of its subject matter: for the most part it is prescriptive, proscriptive, affirmative or critical. Prescriptive theory offers new or revived solutions for specific problems: it functions by establishing new norms for practice. It thus promotes positive standards and sometimes even a design method.

Within the Modern Architectural debate, architects were seen as active agents in the construction of the community and its structures. They would produce man- ifestoes in order to declare an opinion into a strategy for practice and it was not surprising to see many Modern Movement architects defining their formula in the sense of a prescribed program, thus producing prescriptive theories of architecture. The Schröder house, in this sense, was a concrete example of architecture as the built form of prescriptive theory.

In the mid 1960's, challenges to Modern Movement ideology and to a debased and trivialized Modern Architecture accelerated and proliferated to become known as the post-modern critique. The impacts of postmodernism in architecture became clearer by the growth of architectural theory publications as well as the proliferation of theoretical paradigms or ideological frameworks (Nesbitt 1996, 22-28). Through such transformation of the cultural, therefore architectural scene, architects' interpretation of their practice also took another direction. According to Diane Ghirardo, while Modernism vested too much power in the architect to alter and redeem society; the Postmodern architect accepted a modest role by reducing his mission to fulfilling the present day requirements $(1986,3)$. Rather than producing prescriptive frameworks, architects have become more engaged in the expression of their design philosophies through the description and justification of their own work. Accordingly, the architecture of Richard Meier, exemplified here with his Jubilee Church building, is significant of strong theoretical consistency legislated by the architect's preferred vocabulary, conforming to an affirmative model of architectural theory. Starting in the course of the postmodern critique, the expansion within the field of architectural theory has gained acceleration through the following decades, giving way to the pluralist structure of current scenery with its diverse possibilities of orientation. Freed from mostly formal frameworks, the role of the architect has become that of a mediator in the process of reconciliation between the built environment and social, cultural and ecological requirements. Theoretical production in architecture 
has oriented to more critical grounds by evaluating the built world and its relationships to the society it serves. Such critical theory poses alternative solutions based on observations of the current state of the discipline or offers new thought paradigms for approaching the issues. It evaluates the architectural profession, its intentions and its cultural relevance at large. As a key concept in critical theory, sustainability has become a reference point and motivation for contemporary architects as in the case of Marc Koehler Architects who has initiated the Superlofts enterprise with such impetus.

Although this paper has tried to associate certain buildings with certain types of architectural theories and tendencies that correspond to certain time periods, it would be necessary to note that prescriptive, affirmative or critical models of theory are not solely bound to certain movements. It is possible to come across any of them in any time period in history. Moreover, although the buildings stated here stand as the built forms of certain theories, it might be possible to associate them with different theoretical frameworks through different readings. In most cases, a building would not necessarily correspond to one type of theory but would rather reflect a composition of diverse scaffoldings.

The ideas presented in this essay might draw attention to another commonly debated issue; the need for architectural theory in practical use. In the $17^{\text {th }}$ century, the French Classicist literary Jean Racine defined style as "thoughts expressed with the minimum of words" (Collins 1998, 63). It seems that some would rather acquire their style with no words at all as a quote from Rietveld $(1927,162)$ would bring to mind: In my opinion, there is no reason why anyone should provide a justification for making something; on the contrary, the need for concrete expression is removed if one has been able to express that need in words first. And there is no need to explain work which has already been carried out

\section{Kaynakça}

Abel, C. 1988. Analogical Models in Architecture and Urban Design. METU JFA 8 (2), pp.161-188.

Bianchini, R. 2018. Richard Meier, "white buildings make you more aware of the colors of nature" [online]. Available at: https://www.inexhibit.com/marker/ richard-meier-whiteness-makes-you-more-aware-of-the-colors-of-nature/

Chust, P. P. 2014. Towards a Sustainable Architecture. Arte y Politicas de Identidad 10-11, pp. 227-250.

Collins, P. 1998. Changing Ideals in Modern Architecture. Canada: McGill-Queen's University Press.

Dannels, P. Approaching the Iceberg: Richard Meier's Jubilee Church [online]. Available at: https:// imagejournal.org/article/approaching-the-iceberg/

Frampton, K. 1997. Modern Architecture A Critical History, London: Thames and Hudson.

Ghirardo, D. 1986. Past or Post Modern in Architectural Fashion. Journal of Architectural Education (1984- ) 39 (4), pp.2-6. Available at: http://www. jstor.org/stable/1424789 [Accessed: 08/04/2010].

Kruft, H. W. 1994. A History of Architectural Theory from Vitruvius to the Present. USA: Princeton Architectural Press.

Mallgrave, H. F. 2007. Architectural Theory Volume I. UK: Blackwell Publishing.

Nesbitt, K. 1996. Introduction. In: Kate Nesbitt ed. Theorizing a New Agenda for Architecture. New York: Princeton Architectural Press. pp.16-67.

Onofrei, V. 2005. The Theory of Architecture Applications and Connections. Buletinul Institutului Politechnic Din Iaşi, Tomul LI (LV) Fasc. 3-4, pp. 125-137.

Riding, A. 2003. The Vatican's Modernist Moment; $A$ Church designed by Richard Meier Is consecrated in Rome [online]. Available at: https://www. nytimes.com/2003/10/30/arts/vatican-s-modernist-moment-church-designed-richard-meier-consecrated-rome.html.

Rietveld, G. 1927. Utility, Construction: (Beauty, Art). In Benton T. and C. eds. Architecture and Design: 1890-1939. USA: The Whitney Library of Design. 1975. pp.162-163.

Rowe, C. 1975. Introduction. In: Five Architects, New York: Oxford University Press.

Van Doesburg, T. 1922. The Will to Style. In: Benton T. and C. eds. Architecture and Design: 1890-1939. USA: The Whitney Library of Design. 1975. pp.92-94.

Van Doesburg, T. 1924. Plastik bir Mimarlığa Doğru. İçinde: Conrads, U. der. 20. Yüzyıl Mimarisinde Program ve Manifestolar. Șevki Vanlı Mimarlık Vakfi Yayınları. 1991. pp. 64-66.

Warncke, C. P. 1991. De Stijl 1917-1931. Germany: Benedikt Taschen.

Winston, A. 2017. Unfinished Homes Touted as Potential Solution to the Global Housing Crisis [online]. Available at: https://www.dezeen.com/2017/06/16/ unfinished-diy-homes-touted-potential-solution-housing-crisis-kleiburg-refurbishment/

URL 1. Design Philosophy [online]. Available at: https:// www.richardmeier.com/?page_id=8642

URL 2. The Superlofts Block Y [online]. Available at: https://marckoehler.com/wp-content/uploads/ marckoehlerarchitects-bloky-4-1.jpg

URL 3. The Superlofts Houthavens [online]. Available at: https://marckoehler.com/project/ superlofts-houthavens/

URL 4. The Superlofts Story: from a local project to an international adventure [online]. Available at: https://marckoehler.com/story/the-superlofts-story/ 